\title{
Investigation of optical properties of silicon oxynitride films deposited by RF PECVD method*
}

\author{
WoJCIECH KIJASZEK ${ }^{1, \dagger}$, WALDEMAR OLESZKIEWICZ ${ }^{1}$, AdRIAN ZAKRZEWSKI ${ }^{2}$, \\ Sergiusz Patela ${ }^{2}$, MareK TŁaCZaŁA ${ }^{1}$ \\ ${ }^{1}$ Division of Microelectronics and Nanotechnology, Faculty of Microsystem Electronics and Photonics, Wrocław University \\ of Science and Technology, Janiszewskiego 11/17, 50-372 Wrocław, Poland \\ ${ }^{2}$ Division of Microsystems and Photonics, Faculty of Microsystem Electronics and Photonics, Wrocław University of Science \\ and Technology, Janiszewskiego 11/17, 50-372 Wrocław, Poland
}

\begin{abstract}
In this study, the authors deposited silicon oxynitride films by Radio Frequency Plasma Enhanced Chemical Vapour Deposition (RF PECVD) method. The research explores the relationship between the deposition process parameters and the optical properties of the deposited $\mathrm{SiO}_{\mathrm{x}} \mathrm{N}_{\mathrm{y}}$ films. The optical constants of $\mathrm{SiO}_{\mathrm{x}} \mathrm{N}_{\mathrm{y}}$ films were measured and calculated by spectroscopic ellipsometry method. Additionally, the authors investigated the possibility of controlling the deposited film composition by the flow ratio of different gaseous precursors: ammonia $\left(\mathrm{NH}_{3}\right)$, diluted silane $\left(2 \% \mathrm{SiH}_{4} / 98 \% \mathrm{~N}_{2}\right)$, nitrous oxide $\left(\mathrm{N}_{2} \mathrm{O}\right)$ and nitrogen $\left(\mathrm{N}_{2}\right)$. The gas mixture introduced to the working chamber during the growth of the film has the influence on the $\mathrm{Si}-\mathrm{O}$ and $\mathrm{Si}-\mathrm{N}$ bonds formation and the ratio between these bonds determines the refractive index of the deposited film.
\end{abstract}

Keywords: silicon oxynitride; RF PECVD; spectroscopic ellipsometry; reflection coefficient

(C) Wroclaw University of Technology.

\section{Introduction}

Silicon oxynitride $\left(\mathrm{SiO}_{\mathrm{x}} \mathrm{N}_{\mathrm{y}}\right)$ films are a nonstoichiometric material with interesting properties. The $\mathrm{SiO}_{\mathrm{x}} \mathrm{N}_{\mathrm{y}}$ films have diverse parameters, ranging from those of the silicon dioxide $\left(\mathrm{SiO}_{2}\right)$ to the silicon nitride $\left(\mathrm{Si}_{3} \mathrm{~N}_{4}\right)$. The versatile properties of the films create many possibilities of application in different fields such as microelectronics $[1,2]$, optoelectronics [3, 4] or in micro-electro-mechanical systems (MEMS) technology [5].

Silicon compounds such as $\mathrm{SiO}_{2}$ and $\mathrm{Si}_{3} \mathrm{~N}_{4}$ are widely applied dielectrics in microelectronics due to their adequate electrical, thermal and mechanical properties. However, $\mathrm{SiO}_{2}$ dielectric films have reached the technological limit as the properties of silicon dioxide are unsatisfactory for novel micro- and optoelectronic devices. Additionally, the silicon oxynitride films have better not only

\footnotetext{
${ }^{*}$ This paper was presented at XIII Seminar on Surfaces and Thin-Film-Structures, Szklarska Poręba, Poland, 2015.

${ }^{\dagger}$ E-mail: wojciech.kijaszek@pwr.edu.pl
}

dielectric, but also optical properties. The optical losses in $\mathrm{SiO}_{\mathrm{x}} \mathrm{N}_{\mathrm{y}}$ films are significantly lower and the refractive index of the films can be adjusted from 1.46 to around 2.1. Therefore, in the future silicon oxynitride can replace silicon dioxide in the semiconductor industry.

In an earlier study, the authors have deposited $\mathrm{Si}_{3} \mathrm{~N}_{4}$ films by Plasma Enhanced Chemical Vapour Deposition (PECVD) method and investigated their optical properties [6].

In this study, the conditions of the PECVD process were modified in order to manufacture $\mathrm{SiO}_{\mathrm{x}} \mathrm{N}_{\mathrm{y}}$ films. The influence of the gas precursor flow rate on the optical parameters of the deposited films was investigated.

\section{Experimental method}

The investigated silicon oxynitride films were deposited in a commercially available PlasmaLab 80Plus system manufactured by Oxford Instruments. The films were deposited on thermally 
oxidized p-type silicon ( 111 1 1 ) substrates $\left(\mathrm{d}_{\mathrm{SiO} 2}=230 \mathrm{~nm}\right)$ in order to improve the quality of the manufactured $\mathrm{SiO}_{\mathrm{x}} \mathrm{N}_{\mathrm{y}}$ films. The films were deposited using silane diluted in nitrogen $(2 \%$ $\mathrm{SiH}_{4} / 98 \% \mathrm{~N}_{2}$ ), ammonia $\left(\mathrm{NH}_{3}\right)$ and nitrous oxide $\left(\mathrm{N}_{2} \mathrm{O}\right)$ as gaseous precursors. The duration of each deposition process was set at 5 minutes.

In each deposition process the RF signal (13.56 MHz) was supplied to the upper electrode for capacitive plasma coupling and the forward power of the signal was set to $20 \mathrm{~W}$. The pressure was controlled by the APC valve and was stabilized at $86.5 \mathrm{~Pa}$ while the temperature of the table with substrates was stabilized at $350{ }^{\circ} \mathrm{C}$. The flow rates of $2 \% \mathrm{SiH}_{4} / 98 \% \mathrm{~N}_{2}$ and $\mathrm{N}_{2} \mathrm{O}$ were set at $425 \mathrm{sccm}$ and $350 \mathrm{sccm}$, respectively. The set value of $\mathrm{NH}_{3}$ flow rate was different for each deposition process, ranging from 10 to $50 \mathrm{sccm}$.

The spectroscopic ellipsometry studies give information about the thickness and refractive index $n$ value of the deposited $\mathrm{SiO}_{\mathrm{x}} \mathrm{N}_{\mathrm{y}}$ film. The measurements were performed on a J. A. Woollam Co. ellipsometer that makes posible to carry out the measurements at different incidence angles $\left(65^{\circ}, 70^{\circ}\right.$, $75^{\circ}$ ). The parameters were calculated for wavelength ranging from 300 to $1000 \mathrm{~nm}$ with the measurement resolution of $10 \mathrm{~nm}$. The reflection coefficient of the $\mathrm{SiO}_{x} \mathrm{~N}_{y} / \mathrm{SiO}_{2}$ bilayer was measured in a system with integrating sphere.

\section{Results}

The measurements were carried out in order to perform calibration of PECVD process and characterization of optical properties of the manufactured $\mathrm{SiO}_{\mathrm{x}} \mathrm{N}_{\mathrm{y}}$ films. From the measured thickness of the deposited film, the growth rate of the film was calculated. Fig. 1 shows the correlation of the film growth rate with the flow rate of $\mathrm{NH}_{3}$ during the deposition process.

From the analysis of the measured data it follows that the growth rate of the $\mathrm{SiO}_{\mathrm{x}} \mathrm{N}_{\mathrm{y}}$ film is decreasing linearly with the increasing flow rate of $\mathrm{NH}_{3}$. The increase of the $\mathrm{NH}_{3}$ flow rate results in the increase of the nitrogen (ammonia) to oxygen radicals ratio. The active species (ions and

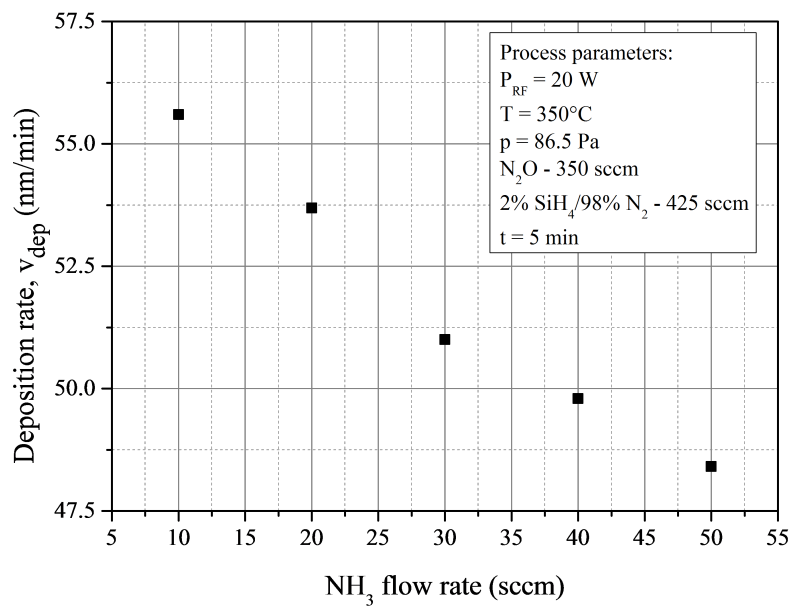

Fig. 1. Growth rate of the $\mathrm{SiO}_{\mathrm{x}} \mathrm{N}_{\mathrm{y}}$ film deposited by the PECVD technique as a function of ammonia flow rate.

radicals) are created by electron-impact ionization and dissociation of precursor gases and they determine the probability of $\mathrm{Si}-\mathrm{N}$ and $\mathrm{Si}-\mathrm{O}$ bonds formation. During the growth of the $\mathrm{SiO}_{x} \mathrm{~N}_{y}$ films deposited utilizing PECVD method, the most probable reaction is the formation of the $\mathrm{Si}-\mathrm{O}$ bonds. The increase of the reactive species containing nitrogen results in the oxygen deficiency and formation of $\mathrm{Si}-\mathrm{N}$ bonds [7].

As it is known, the deposition rate of the $\mathrm{SiO}_{2}$ films manufactured by PECVD method is few times higher comparing to the deposition rate of $\mathrm{Si}_{3} \mathrm{~N}_{4}$ films. Therefore, it could be expected that the increase of the $\mathrm{NH}_{3}$ flow rate will result in the lower growth rate of the $\mathrm{SiO}_{\mathrm{x}} \mathrm{N}_{\mathrm{y}}$ film and higher concentration of nitrogen in the composition of the deposited film. The changes of the composition and bonding configuration of the deposited $\mathrm{SiO}_{\mathrm{x}} \mathrm{N}_{\mathrm{y}}$ films should be verified by the X-ray photoelectron spectroscopy investigation.

The changes in the composition of $\mathrm{SiO}_{x} \mathrm{~N}_{y}$ have an influence on the optical properties of the deposited film. The ellipsometric studies showed that the refractive index of the $\mathrm{SiO}_{\mathrm{x}} \mathrm{N}_{\mathrm{y}}$ films was increasing with the flow rate of $\mathrm{NH}_{3}$. In the investigated range of the set $\mathrm{NH}_{3}$ flow rates values, the refractive index of the films was changing from 1.51 to 1.55 . The values of the refractive index of the investigated $\mathrm{SiO}_{\mathrm{x}} \mathrm{N}_{\mathrm{y}}$ films, measured for 
the spectral wavelength of 300 to $1000 \mathrm{~nm}$, are presented in Fig. 2.

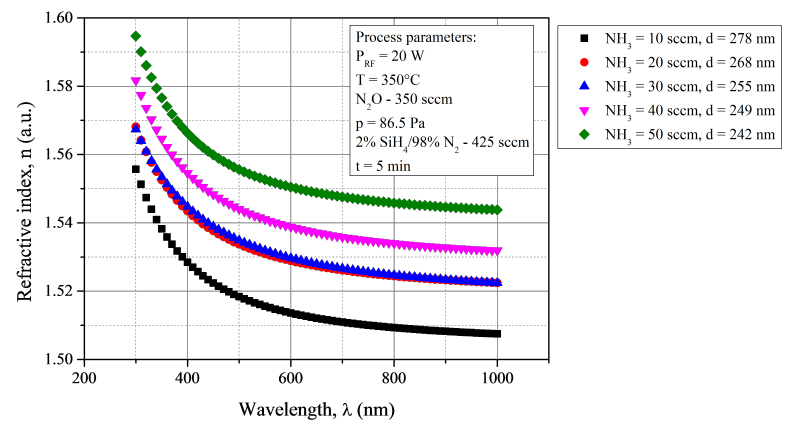

Fig. 2. Refractive index as a function of wavelength for $\mathrm{SiO}_{\mathrm{x}} \mathrm{N}_{\mathrm{y}}$ films deposited at different $\mathrm{NH}_{3}$ flow rates.

The values of the refractive indexes of the investigated $\mathrm{SiO}_{\mathrm{x}} \mathrm{N}_{\mathrm{y}}$ films are close to the value specific for silicon dioxide. Therefore, it means that in the bonding configuration of the deposited films, the $\mathrm{Si}-\mathrm{O}$ bonds are dominant. From the analysis of the acquired measured data it follows that the refractive index of the deposited $\mathrm{SiO}_{\mathrm{x}} \mathrm{N}_{\mathrm{y}}$ films can be precisely controlled by the $\mathrm{NH}_{3}$ flow rate. The refractive index and composition of the $\mathrm{SiO}_{\mathrm{x}} \mathrm{N}_{\mathrm{y}}$ films are mainly influenced by the ratio between $\mathrm{SiH}_{4} / \mathrm{N}_{2} \mathrm{O}$ flow rates. Reduction of the $\mathrm{N}_{2} \mathrm{O}$ flow rate should result in growth of the films with higher refractive index.

The refractive index of silicon oxynitride can be modified in a wide range from 1.46 to 2.1. The possibility creates many application solutions of the films in the technology of micro- and optoelectronic devices. The investigated films also have very low extinction coefficient value $(\mathrm{k})$, lower than the sensitivity of the ellipsometer applied for the measurements $\left(\mathrm{k}<10^{-7}\right)$.

To investigate the applicability of the $\mathrm{SiO}_{\mathrm{x}} \mathrm{N}_{\mathrm{y}}$ films for antireflective coatings, the reflection coefficient of the $\mathrm{SiO}_{\mathrm{x}} \mathrm{N}_{\mathrm{y}}$ films deposited on $\mathrm{SiO}_{2}$ buffer layer was measured. The value of the reflection coefficient from the $\mathrm{SiO}_{\mathrm{x}} \mathrm{N}_{\mathrm{y}} / \mathrm{SiO}_{2}$ bilayer was measured for wavelengths ranging from 250 to $1000 \mathrm{~nm}$ (Fig. 3). The measurements were carried out in a system with the integrating sphere in order to improve the detectability of the light that was scattered or reflected by the surface roughness, $\mathrm{SiO}_{\mathrm{x}} \mathrm{N}_{\mathrm{y}} / \mathrm{SiO}_{2}$ interface or material inhomogeneity. Therefore, the measured value of the reflection coefficient is more accurate.

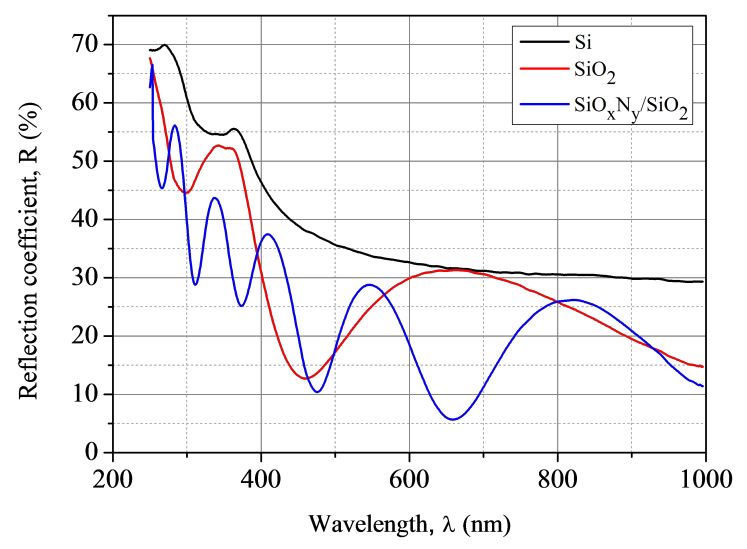

Fig. 3. Comparison of reflection coefficients of the $\mathrm{Si}$ substrate, $\mathrm{SiO}_{2}$ buffer and $\mathrm{SiO}_{2} / \mathrm{SiON}$ bilayer.

In the measured spectra, oscillation of the reflection coefficient value is observed. The oscillations are present due to the interference of the incident radiation and the radiation reflected from the interfaces of different materials. The number and locations of the peaks are dependent on the number of interfaces, thickness of the layers and construction of the antireflection coating. The investigated bilayers of $\mathrm{SiO}_{\mathrm{x}} \mathrm{N}_{\mathrm{y}} / \mathrm{SiO}_{2}(\sim 250 / 230 \mathrm{~nm})$ films are thicker comparing with the $\mathrm{Si}_{3} \mathrm{~N}_{4}$ and $\mathrm{Nb}_{2} \mathrm{O}_{5}(\sim 60 \mathrm{~nm})$ or $\mathrm{TiO}_{2} / \mathrm{SiO}_{2}(\sim 10-130 / 40$ $60 \mathrm{~nm})$ multilayer antireflection coatings [8-10]. Due to the fact, the number of oscillations in the measured spectra is higher than normally and can be reduced by the decrease and optimization of the thickness of the deposited films.

From the measured data it follows that the investigated $\mathrm{SiO}_{\mathrm{x}} \mathrm{N}_{\mathrm{y}}$ films can be applied as antireflective coatings. It is possible to precisely control the value of the refractive index of the $\mathrm{SiO}_{\mathrm{x}} \mathrm{N}_{\mathrm{y}}$ in a wide range of values by the deposition process parameters. The mentioned advantage of the investigated films makes them interesting in the design of optical layers, because it is possible to adjust the refractive index of the film to a specific material system (i.e. silicon or AIIIBV semiconductor compounds). 


\section{Conclusions}

The silicon oxynitride films were deposited by PECVD method on oxidized silicon substrates. The flow rate of the $\mathrm{NH}_{3}$ during the growth of the film was modified in each deposition process in order to obtain films with different $\mathrm{Si}-\mathrm{O}$ and $\mathrm{Si}-\mathrm{N}$ bonding fractions. The optical properties of the $\mathrm{SiO}_{x} \mathrm{~N}_{y}$ films were investigated using spectroscopic ellipsometry. Additionally, the bilayer consisting of $\mathrm{SiO}_{\mathrm{x}} \mathrm{N}_{\mathrm{y}}$ and $\mathrm{SiO}_{2}$ was measured as an antireflective coating.

The study showed that the properties of the deposited $\mathrm{SiO}_{\mathrm{x}} \mathrm{N}_{\mathrm{y}}$ film can be modified and controlled by the flow rates of the gaseous precursors. The value of the refractive index of the deposited film can be controlled, so it is possible to obtain films with specified optical properties. Moreover, the deposited films have been found to be of very good optical quality. The value of the extinction coefficient of the investigated films was lower than the sensitivity of the applied ellipsometer. Therefore, the $\mathrm{SiO}_{\mathrm{x}} \mathrm{N}_{\mathrm{y}}$ films manufactured by PECVD technique can be successfully used for optoelectronic and photonic applications such as antireflective coatings, optical filters or waveguide layers.

The future works will concern the application of silicon dioxide, silicon nitride and silicon oxynitride in the technology of micro- and optoelectronic structures (Bragg reflectors, optical filters and antireflective layers for photovoltaic cells, LEDs and photodetectors).

\section{Acknowledgements}

This work was co-financed by the European Union within European Regional Development Fund, through grant Innovative Economy (POIG.01.01.02-00-008/0805), by National Centre for Research and Development through Applied Research Program grant no. 178782 and ITE/PBS2/A3/15/2013/PWr, by Wroclaw University of Science and Technology statutory grants and Slovak-Polish International Cooperation Program no. SK-PL-0005-12.

\section{References}

[1] Do J. H., Kang H. S., Kang B. K., Microelectron Eng 85 (2008), 1820.

[2] Szekeresa A., Nikolova T., Simeonov S., Gushterov A., Hamelmann F., Heinzmann U., Microelectron J 37 (2006), 64.

[3] Brinkmann N., SOMmer D., Micard G., Hahn G., Terheiden B., Sol Eng Mat Sol C 108 (2013), 180.

[4] Sharma S. K., Barthwal S., Singh V., KuMar A., Dwivedi P. K., Prasad B., Kumar D., Micron 44, 2013, 339.

[5] LiU Y., LiN I.-K., Zhang X., Mat Sci Eng: A 489, Iss 1-2 (2008), 294.

[6] KijaszeK W., Oleszkiewicz W., Zakrzewski A., Patela S., TŁaczaŁA M., Proceedings of 2013 International Young Students and Scientists "Photonics and Microsystems", 1214.07.2013, St Marienthal, Germany, 42.

[7] Hussein M. G., Wörhoff K., Sengo G., DrIESSEN A., Thin Solid Films 515 (2007), 3779.

[8] Duttagupta S., Ma F., Hoex B., Mueller T., Aberle A. G., Energy Procedia 15 (2012), 78.

[9] Mazur M., SzymańsKa M., Kaczmarek D., Kalisz M., WojcieszaK D., DomaradzKi J., Placido F., Appl Surf Sci 301 (2014), 63.

[10] Mazur M., Wojcieszak D., DomaradzKi J., KaczmareK D., Song S., Placido F., OptoElectron Rev 21(2), 233. 